\title{
O PROCESSO DE SOCIALIZAÇÃO E A SOLIDARIEDADE
}

\author{
Paulo de Salles Oliveira ${ }^{1}$
}

Resumo: Vivemos numa sociedade marcadamente individualista e consumista, cujas repercussões interferem nas diversas maneiras como se desenvolve a sociabilidade. Entendê-las demanda esforço, porém mais complexo ainda é o desafio para encontrar modos de superação dos impasses envolvidos nessas questões. Seria possível identificar relações enraizadas e profundas de convivência social, lastreadas na solidariedade e com possibilidade de se expandirem de forma generalizada no seio da sociedade? A discussão parte de conceitos de socialização baseados na verticalidade das interações, passando pelas interpretações em que há espaço para influências recíprocas entre os sujeitos e se encerra com a aproximação entre socialização e cultura solidária, buscando um caminho alternativo. Conquanto ainda modesto, ele é concreto, pois vivenciado por pessoas que estão ao mesmo tempo tão próximas a nós e, muitas vezes, distantes de nossa percepção.

Palavras-chave: Socialização. Reciprocidade. Solidariedade. Diferenças. Cultura solidária.

A ideia de socialização: entre a verticalidade e a reciprocidade de influências na formação social dos indivíduos

Para melhor entender o processo de socialização, partimos da associação feita por Durkheim (1971) entre socialização e educação das crianças. Para ele, educar significa "a ação exercida pelas gerações adultas sobre as gerações que não se en-

1 Universidade de São Paulo, São Paulo-SP, Brasil . 
contram ainda preparadas para a vida social" (pp. 39-48). Assim como a educação, também a socialização vem sendo marcada há muito tempo pelo direcionamento quase unilateral na formação dos indivíduos para viverem em sociedade. Coube sempre aos mais velhos a tarefa de constituição dos novos e futuros sujeitos sociais, esperando-se que os mais jovens pudessem acolher e assimilar.

Um conhecido manual nas ciências sociais, organizado por Octavio lanni e Fernando Henrique Cardoso, traz no capítulo sobre socialização a seguinte definição:"ato de inculcar a estrutura de ação de uma sociedade no indivíduo ou grupo" (Lévy Jr., 1968, p. 61). Inculcar significa apontar, apregoar, demonstrar, aparentar, dar a entender, indicar, revelar, recomendar, propor, aconselhar. Mas também: impor-se, insinuar-se, repetir alguma coisa com insistência para frisá-la no espírito, repisar.

Tais conceitos acabaram por conferir à socialização nos dias atuais uma imagem pesada, como se uma forma modeladora se impusesse sobre nós, de modo a incrustar em nosso interior modos de ser e de agir. Esse aspecto foi captado muito significativamente pelo romance memorialista, O Ateneu, de Raul Pompéia, em conhecida passagem, na qual o menino Sérgio é deixado na porta do internato pelo pai, com a recomendação de que ali irá se encontrar com o mundo, necessitando coragem para essa luta. Mostra uma ruptura traumática, violenta e brusca, na qual o mundo, a que se reporta o pai do menino, aparece em nítido contraste com a estufa de carinho ou com o aconchego placentário - expressões usadas pelo autor - que teriam marcado ate então a vida familiar do menino.

A quem cabe promover a ação de apregoar os valores sociais, as regras, os preceitos de conduta que a sociedade convencionou como adequadas para sua existência e sobrevivência? Às gerações maduras, aos mais velhos. Compete a eles assumir essa responsabilidade, pois nenhuma criança quando vem ao mundo poderia criar-se sozinha, por si mesma. É possível supor que autores como Durkheim sentissem necessidade de realçar a verticalidade no sentido de firmar uma posição que destacasse os aspectos sociais na formação dos indivíduos, ou seja, objetivavam não tanto valorizar a unidirecionalidade da ação, mas, sim, enfatizar que a socialização envolvia, preponderantemente, aquisições socialmente adquiridas em oposição a interpretações que acentuavam os determinismos hereditários.

Socialização pode, assim, ser considerada um processo pelo qual o indivíduo é introduzido no convívio social, absorvendo e interiorizando proposições e modos de ser consagrados coletivamente. Envolve um movimento dialético que se trava entre indivíduo e sociedade, no qual se dá o encontro entre um conjunto de práticas e maneiras de existir, já objetivadas socialmente e, portanto, chanceladas por um grupo mais amplo, e sua interiorização pelos indivíduos, de modo que estes se sintam articula- 
dos a esse grupamento maior e, por assim dizer, formados para a vida em coletividade. Trata-se de um processo que tem um marco inicial e principia logo que o indivíduo nasce, mas que não tem fim e se desenrola ao longo de toda a vida desse mesmo indivíduo, como mostra Lapassade (1963). É algo dinâmico, porém não linear, ou seja, pressupõe rupturas, retomadas de rumo, idas e vindas.

Entretanto, se o nascimento é em si um fato importante, tanto biológica quanto socialmente, é preciso considerar que o ato de vir ao mundo não nos torna, de imediato, membros de uma sociedade. Nascemos, sim, com inclinação à sociabilidade, mas esta precisa ser desenvolvida em nós e é justamente em função desse preparo que nos tornamos habilitados para a vida e para o convívio com nossos semelhantes.

Os indivíduos se tornam sujeitos sociais quando compreendem e vislumbram um sentido no arcabouço que herdam de gerações antecedentes. É importante, porém, realizar uma distinção: uma coisa é o fato de esse conjunto de práticas e ideias tornar-se inteligível a cada um, a ponto de também compreendê-lo e até lhe atribuir um significado, em conformidade com aquilo que foi transmitido. Isso não quer dizer, todavia, que cada indivíduo necessariamente venha a concordar com esses pensamentos e práticas, ou mesmo que estes soem como congruentes. Temos a capacidade de compreender as oferendas legadas pelos predecessores, mas nem sempre acatá-las na vida individual. O importante, entretanto, nesse primeiro momento, é compreender e respeitar, como enfatiza Bourdieu (1999), apoiado no preceito de Spinoza de "não deplorar, não rir, não detestar, mas compreender" (p. 9).

Se compreender é um passo significativo, os problemas não param por aí. Porque podemos compreender, respeitar, porém não aceitar. Esta parece ser uma das vertentes dos conflitos entre gerações, ou ainda daqueles vividos no interior de uma mesma geração. A dissonância repousa justamente na ausência de um senso comum, no sentido que lhe empresta Arendt (1988), ou seja, daquela percepção em que meus cinco sentidos individuais estão afinados a um único mundo, comum a todos nós. As crises irrompem, segundo essa autora, cada vez que se destrói uma parte desse mundo que é comum a todos nós. Seria importante esclarecer, valendo-se de Martins (2008), que esse senso é comum "não porque seja banal, mas porque é conhecimento compartilhado entre os sujeitos da relação social" (p. 54). Quer dizer, esse senso comum, verdadeiro arcabouço partilhado de práticas e significados, precede a interação social e lhe dá sustentação.

Um conflito essencial eclode, diz Hannah Arendt, quando nos sentimos descompromissados para com essa percepção comum, que supõe interiorizar a presença do outro, e abrange o universo que habitamos. A autora exemplifica com a menção a certos pais que, no exercício de suas atribuições socializadoras, muitas vezes dão as costas a esse mundo, 
orientando seus filhos num sentido inverso. Ou seja, em vez de aproximá-los, procuram livrar e proteger seus filhos do mundo. Parece fora de dúvidas que alguma proteção seja necessária, sobretudo para as crianças bem pequenas. Contudo, esses pais não parecem se importar com o fato de que - se os filhos devem ser protegidos - o mundo também precisa de proteção concomitante, para não ser destruído pelo assédio acrítico e avassalador do novo ou pela pilhagem de consciências banhadas pelo mais entranhado individualismo de interesses. Sob a capa de direitos individuais - os que temos de fato e outros que presumimos ter -, alguns, na ânsia de exteriorizar práticas e ideias livremente, acabam não contendo impulsos no instante em que deveriam fazê-lo e assim invadem o espaço do outro, conformando uma agressão, mesmo que inadvertidamente. Tem origem aí o desafio de se conciliar a dimensão integradora dos indivíduos no processo de socialização ao esposar práticas e ideias comuns e, nesse mesmo movimento, de preservar a riqueza que se aloja nas diferenças das pessoas entre si.

Durkheim (1977) explica que essas dissonâncias entre a consciência coletiva e o agir individual se devem ao estado de anomia - que não significa propriamente ausência de regras, mas sim a impossibilidade de uma norma geral, sancionada no coletivo, sensibilizar e mover todas as consciências individuais. A anomia é sério obstáculo ao senso comum, e a impossibilidade do senso comum, no sentido usado por Arendt e Martins, tem largas e graves implicações. Porque os indivíduos não apenas resistem em assumir o mundo que lhes foi apresentado, como também resistem a assumir compromissos, desobrigando-se de se empenharem em melhorá-lo ou em transformá-lo. Comprometer-se seria um sair de si mesmo em nome da adesão a causas que superam os interesses individuais. Ao contrário, a fragmentação, a percepção isolada das necessidades imediatas, a necessidade de gratificação instantânea, resultando numa visão egocêntrica do mundo favorecem a deserção em sensibilizar-se pelo outro e em trabalhar pelo aprimoramento da justiça social.

Por isso, assumir o mundo é um ponto essencial do processo de socialização, pois abraçar compromissos para com a sociedade indica uma postura em que os indivíduos não se percebem mais isolados e, sim, articulados a uma dimensão societária mais ampla, que os inclui e também os ultrapassa. Esse é o momento da interiorização, no qual não somente podemos compreender os processos subjetivos momentâneos do outro, mas também entender que este mundo em que vivemos é nosso, nos pertence e é feito, em maior ou menor medida, à nossa feição. Conforme mostram Berger e Luckmann (1993),"agora, cada um de nós não somente compreende as definições das situações partilhadas, mas somos capazes de defini-las reciprocamente" (pp. 174-175).

Esse é o instante em que podemos fazer abstrações. Somos agora capazes de abstrair situações e atribuições. Passamos a nos identificar 
não apenas com o outro a quem conhecemos de perto, mas podemos nos identificar com o outro em geral ou a uma generalidade de outros.

Florestan Fernandes oferece um exemplo ao mesmo tempo eloquente e singelo desse aspecto, quando discorre sobre as brincadeiras tradicionais de grupos de crianças em São Paulo. Diz ele que:

o interessante é que justamente por causa da ação despersonalizadora sofrida, no tempo e através dos vários grupos infantis, de criança a criança, (estes brinquedos) se referem mais a funções sociais, a entes gerais, que a pessoas ou atos indicáveis a dedo. (Fernandes, 1979, p. 173)

Florestan mostra, desse modo, como essa socialização não se refere mais à mera imitação dos adultos pela criança, mas, sim, a uma aquisição das atribuições sociais pelas crianças; portanto, é um movimento que não mais se explica, exclusivamente, a partir da geração mais velha para as crianças, mas que se realiza também por elas, entre si. Essa faceta de autonomia relativa das crianças indica pontos importantes. Mostra que a socialização comporta um jogo fluido de influências, na expressão da gerontóloga francesa Claudine Donfut (1988), jogo esse em que as transmissões dificilmente são associadas sem modificações ou recriações. Por isso mesmo, ou seja, por essas surpresas e reelaborações, dirá Chombart de Lauwe (1991) na mesma direção que esse processo remete não mais à socialização como movimento monolítico, mas a universos de socialização, como brilhantemente mostrou em seu livro Um outro mundo, a infância.

Dessa maneira, se há uma dimensão integradora dos indivíduos no processo de socialização, coabita com ela, no mesmo movimento, uma dimensão capaz de diferenciar as pessoas entre si. Quer dizer, trata-se de um mundo povoado por tensões, um universo pleno de contradições.

Uma das buscas por superar esses impasses talvez possa ser empreendida justamente procurando outras fontes e possibilidades interpretativas, fontes que ultrapassem a unilateralidade da ação de uma geração sobre outra e que possam captar a reciprocidade de influências entre gerações, sem negar, porém, a precedência, a responsabilidade social e a importância dos mais velhos. Vale aqui a conhecida passagem de Marx (1969), na qual explica que os homens fazem sua própria história, mas sempre dentro de circunstâncias determinadas, que são dadas e legadas pelo passado. Por isso, diz ele, "a tradição de todas as gerações mortas" repercute fundo "sobre o cérebro dos vivos" (p. 17).

Nossa pergunta, então, passa a ser esta: como a Psicologia Social poderia contribuir para situar e nuançar os meandros complicados desse processo?

Berger e Luckmann (1985) reforçam a tendência de valorização das interações sociais ao afirmarem que o"o indivíduo não nasce membro de 
uma sociedade. Nasce com predisposição para sociabilidade e torna-se membro da sociedade" (p.173). Esses mesmos autores trazem à tona um aspecto especialmente interessante ao sublinharem que a socialização se realiza com conteúdos cognitivos e conteúdos emocionais. Afirmam ainda que, sem essa ligação emocional, o processo de aquisição de práticas e valores seria muito difícil, quando não impossível.

Quando se pensa, então, na associação do processo de socialização aos recém-nascidos ou às crianças de pouca idade, não há dúvida de que uns e outros não se bastam a si mesmos e precisam realmente da presença adulta - dos pais, dos avós, dos familiares ou dos cuidadores - para serem criados e formados. A pergunta que emerge, então, é a seguinte: e depois? Quando é que os jovens poderiam se formar por si mesmos? A partir de qual momento poderiam eles também influenciar no processo de socialização, agora não mais apenas sendo socializados, e, sim, também exercendo sua ação socializadora sobre as gerações mais velhas?

Muitas vezes, nem é preciso esperar esse depois. Em certos casos, basta o nascimento de um filho para que o pai ou a mãe, mesmo que jovens, ao olharem e tocarem aquela criatura, modifiquem profundamente sua maneira de ver o mundo e o modo como enxergam a si próprios e a relação com os outros. Quem, senão a criança, poderia ter suscitado a mudança?

Outras situações podem mostrar algo semelhante, como Oliveira (2011), pesquisa que focalizou crianças cuidadas por seus avós nas classes populares. Em alguns casos, os pais apenas deixavam as crianças com os avós durante parte do dia, na qual iam trabalhar. Noutros, não puderam assumir o encargo de criação; e houve situações em que não mais quiseram fazê-lo. Nesse último cenário, o descompromisso dos pais quase impeliu os avós a assumirem a criação dos netos. Mas aí advém a surpresa: junto com o componente dramático da rejeição, algo de extraordinário ocorre. A mera presença física das crianças ali, diante dos avós, os leva a reunir todas as energias de que dispõem - e mais aquelas que nem imaginariam mais armazenar - para levar adiante esse desafio que a vida lhes pôs.

"Antes", diz dona Jacira, uma destas avós

quando eu só trabalhava, antes de pegar estas crianças, era serviço, serviço, serviço. Eu vivia sempre doente, tinha problemas cardíacos... Agora eu sarei! Sabe que eu sarei? Não me deu mais nada... a coluna, que o médico falava tanto, não amolou mais. (pp. 171-172)

Pode-se divisar como a socialização não é apenas uma ação que parte dos mais velhos para os mais jovens, dos adultos para as crianças. É uma via de mão dupla. Quer dizer, as crianças, mesmo que muitas vezes não o saibam, levam os mais velhos a modificarem seus modos de ser, 
suas maneiras de agir e pensar. A socialização de uns envolve a ressocialização de outros. E tanto crianças quanto adultos e velhos saem modificados.

Uma das questões centrais em Oliveira (2011) foi estudar de que modo essas pessoas - avós e netos - se modificaram reciprocamente, especialmente os avós, contrariando a crença bastante difundida de que uma pessoa, por ser mais velha, não muda mais.

Avós e netos, crianças e velhos são personagens relegadas e parecem pouco contar nas representações predominantes no interior de nossa sociedade. São pessoas excluídas até mesmo gramaticalmente. Por exemplo: não raro indagamos ao velho:"o que o senhor fez na vida?". Ou, então, à criança: "o que você vai ser quando crescer?". Inadvertidamente ou não, agimos como se para eles não existisse presente. O velho já foi; a criança ainda vai ser.

Parece fora de dúvidas que os mais velhos são pessoas que se sentem à margem. Mesmo que tragam para casa o dinheiro da aposentadoria ou da pensão por viuvez (e aumenta significativamente no Brasil a percentagem de idosos que são arrimos de família) ${ }^{2}$ ou mesmo que mostrem serventia como mão de obra prestadora de serviços, ainda assim sua opinião não parece contar, e suas maneiras e crenças são, reiteradas vezes, tidas como ultrapassadas, defasadas e, portanto, inadequadas para os dias atuais.

Reedita-se aqui a questão colocada num trecho do filme Estamos todos bem (dirigido por Giuseppe Tornatore, 1992), no qual o personagem central, vivido por Marcello Mastroianni, dialoga com uma amiga num baile. Falam a propósito desses desencontros entre filhos e pais. Num dado momento, a mulher aconselha-o a fazer um esforço para não levar tão a sério esses graves problemas: "Veja, Mateo", diz ela, "às vezes é mais fácil fingir que não houve nada... não entender e não procurar esclarecimentos. Pode ser até divertido! Do contrário, é preciso esperar por todo tipo de coisa. Até ser rejeitado pelos próprios filhos".

Os velhos sentem a ambiguidade de estar, ao mesmo tempo, entre os seus, mas de um modo deslocado, sem saber ao certo o lugar que ocupam, o que os leva muitas vezes a nutrir na alma o desejo contraditório do descanso perante a vida. Como poderá se sentir quem não se percebe, de fato, em lugar algum?

Essa pergunta foi colocada por Clastres (1978) em um estudo muito instigante intitulado "O Arco e o Cesto". Apresenta uma simbologia entre os índios Guaiaqui, em que o arco é associado ao homem, e o cesto, à mu-

2 Luís Nassif mostra que: "0 ponto mais relevante (da pesquisa do IBGE sobre os idosos) é o dado de que 64\% dos idosos são arrimos de família. Quando se fala em reduzir a aposentadoria, em estabelecer idades mínimas mais elevadas, sem levar em conta 0 valor da aposentadoria ou da faixa social do aposentado, 0 que se está fazendo é mirar no coração de uma política social das mais relevantes. Significaria jogar essas famílias na rua" (http:// colunistas.ig.com.br/luisnassif/2006/12/02/0s-arrimos-de-familia). 
Iher. $\mathrm{O}$ autor descobre também que havia, entre esse povo, um homem que, em razão dos azares na caça, não podia mais usar o arco e a flecha, sendo obrigado a carregar o cesto. Sem arco, só podia se dedicar à caça de tatus e quatis, capturados com as mãos. Essa prática, embora comum entre os índios, não possuía a mesma dignidade dos atributos da caça com arco. Era viúvo, mas, como era um panema (envolvido pelos azares), nenhuma mulher se interessava por ele - mesmo que fosse na condição de marido secundário, já que a poliandria era prática adotada na tribo.

Esse índio também não está integrado a seus familiares, pois a presença de um homem tido como sem competência técnica para caçar era duplamente indesejável: não trazia caça, mas tinha apetite. Era, além disso, objeto de zombaria generalizada.

Mostrava-se inquieto, nervoso e descontente. Podemos facilmente imaginar como a agressividade lançada contra ele pode ter produzido sentimentos de abandono e de rejeição, pois, embora tivesse sido obrigado a renunciar parcialmente às determinações masculinas, permanecia um homem e se recusava a ser associado às mulheres. Sua condição era inédita, pois não estava em lugar algum que fosse nitidamente identificável nos preceitos lógicos da vida societária dos Guaiaqui. Sua figura se colocava, emblematicamente, como ponto de contato entre duas regiões consagradamente separadas. Carregava o cesto, mas

colocava a tira sobre o peito e nunca sobre a testa. Era claramente uma maneira desconfortável e muito mais fatigante do que a outra para transportar a cesta; mas, era também para ele o único meio de mostrar que, mesmo sem arco, continuava sendo homem. (Clastres, 1978, p.78)

O mesmo sentimento de não se sentir em lugar algum foi experimentado pelos velhos em Oliveira (2011), em razão daquilo que já foi apontado e inclusive por se sentirem um peso dentro de casa. Essa posição errante também deve ter sido experimentada por algumas das crianças, especialmente aquelas que os pais se desincumbiram de sua criação, depositando a responsabilidade nos ombros dos avós. Como experimentar sem sofrimento as dores da rejeição?

Assim, velhos e crianças se viram compelidos a um desafio inesperado e a redefinir, conscientemente ou não, os rumos de sua vida e de sua posição na sociedade. É interessante perceber, então, que o drama vivido por eles desencadeia uma luta travada em comum para que recuperem suas forças e desenhem, em conjunto, um novo destino para suas vidas. Nesses instantes agudos, se percebe como é bom contar com a afeição, o apoio e o calor de pessoa próxima ao nosso lado. $\mathrm{O}$ amparo mútuo e a aceitação em comum do desafio mostram o momento instigante da gestação de um projeto de vida, que vai ganhando seus primeiros contornos. No momento em que esse processo se desencadeia, a vida vai assumindo 
ares mais radiantes, e a convivência suscita momentos ricos de socialização para as crianças e de ressocialização para os mais velhos. São experiências vividas e divididas solidariamente: é o afago na hora difícil, a mão carinhosamente reconfortante a amparar, as novidades experimentadas de parte a parte, fazendo da experiência diária uma fonte mútua de renovação. Constroem, por isso mesmo, vidas compartilhadas.

\section{Socialização e reciprocidade}

Se a socialização também pode sugerir reciprocidade, o que é partilhado nessa socialização recíproca? Valho-me, ainda, dos avós e netos.

A primeira grande lição talvez seja o fato de que não procuraram camuflar suas diferenças. Assumiram e cultivaram suas particularidades na convivência diária, mas o fizeram respeitando o outro na busca de relações igualitárias de existência. Somos iguais nos direitos e deveres enquanto pessoas, mas somos diferentes em nossos traços particulares.

Estamos diante de sujeitos diferentes na idade, mas que coabitam um mesmo mundo. Esse mesmo mundo, no entanto - em razão das peculiaridades das vivências -, é visto de modo diverso por velhos e crianças. Um ponto essencial é que a coabitação de pessoas diferentes não necessariamente leva à reciprocidade na socialização, pois poderia ocorrer exatamente o contrário, ou seja, a rejeição, a recusa de aceitar o outro tanto como interlocutor quanto como pessoa confiável para discutir problemas individuais. Nesse contexto, prevaleceria a relutância em identificar nesse outro alguém capaz de entender e de ajudar.

Quando, porém, seres humanos se reconhecem ao mesmo tempo como iguais (nos direitos e deveres enquanto pessoas) e diferentes (em suas particularidades), o cenário muda de figura. Abre-se terreno para a socialização recíproca, ou seja, cada geração se dispõe a partilhar com a outra suas maneiras de agir e de interpretar o mundo; cada uma se coloca como emissora e receptora de cultura alternadamente.

A premissa de suas vidas é dividir com o outro, ou, numa única palavra: compartilhar. Para os mais velhos, as crianças são fonte de renovação. Ensinam a ler, a escrever, a falar (corrigindo seus erros), explicam as matérias da escola, trazem para casa as novidades, contam as coisas do bairro e não se sentem envergonhados em convidar seus avós para brincar. Quem, na condição adulta, se lembra de convidar os mais velhos para partilhar alegrias? Os netos de dona Rosalina tanto faziam que conseguiam que sua avó saísse correndo atrás deles na brincadeira do lenço; os de dona Alda a convidavam para cantar e dançar nas chamadas festinhas que faziam no terraço. Quem poderia avaliar o quanto esse gesto, aparentemente simples e despretensioso, encoraja e leva os mais velhos a bus- 
car - e a encontrar - uma energia que eles mesmos já julgavam perdida irreversivelmente no tempo?

Não ter vergonha de brincar e de conviver com os velhos, familiarizá-los com as novidades, dividir conhecimentos obtidos na escola - eis uma parcela do ensinamento das crianças com quem estive. Generosidade, despojamento, percepção orientada para as necessidades do outro, ainda que isso implique enorme sacrifício - eis a grande oferenda e lição dos idosos.

Já aqui se pode antever como a situação criada - de alguém assumir (ou, conforme o caso, ajudar) a criação dos netos - leva os mais velhos a modificarem seus modos de ser. Pessoas que se achavam muitas vezes relegadas, pesadas, inadequadas, deslocadas dentro da vida familiar, agora têm um novo e inesperado desafio a enfrentar. E, ao aceitarem esse desafio, implicitamente se abrem para uma mudança nada desprezível. Não se recusando a assumir a responsabilidade pelas crianças, serão levadas a alterar muito mais do que a rotina de vida. Inesperadamente, se dispõem para uma nova atuação e para uma nova compreensão das injunções da vida. Redescobrem dentro de si um vigor que já imaginavam perdido; redefinem modos de agir e de pensar. Essas modificações, muitas vezes, escapam-Ihes à consciência. Mas, se os velhos não notam, seus próprios filhos denunciam aquilo que, para estes, se afigura como gestos de surpreendente tolerância e benevolência: "Com eles (referindo-se às crianças), você faz assim, mas com a gente foi muito diferente!".

Ao não se dar conta de quanto mudaram, alguns idosos chegam a relutar em admitir a transformação. Mas o fato é que, na condição de responsáveis por seus netos, se sentem novamente religados à dinâmica da vida, reposicionados e reconhecidos como seres viventes. A missão que a vida Ihes depositou sobre os ombros os repõe como seres atuantes no mundo presente. Se antes se viam apartados, desviados, gramaticalmente excluídos, não se percebendo em lugar algum, no exato momento em que assumem cuidar dos netos abraçam, simultaneamente, um comprometimento maior com a vida. Por isso, recobram o ânimo e acabam elaborando uma proposta de vida, um projeto em que há expectativa e há futuro.

Para as crianças, por sua vez, com os avós ali por perto, fica mais fácil e afetuoso encarar o presente e, além disso, inaugura-se a possibilidade de travar maior contato com coisas preciosas que vêm de um tempo distante. $O$ passado é narrado com o calor, o sofrimento, a ternura ou a alegria de quem o viveu. Os avós aqui tratados ou foram pessoas do campo ou, então, imigrantes nordestinos. As crianças ficaram sabendo, graças a eles, que água não vem da torneira e, sim, do rio, para onde seus avós quando jovens eram obrigados a caminhar, por léguas e léguas, para lavar roupa. As roupas eram postas nas bruacas, atadas nos dorsos dos burros, e as pessoas iam a pé. Esse pormenor não deixa de causar espanto 
nas crianças. Elas se dão conta de que hoje a vida é dura, mas talvez tenha sido ainda mais árdua numa época em que era muito raro aos pobres o acesso à escola; tempo em que as crianças não tinham voz e eram ensinadas a sair da sala quando chegasse uma visita e a não interromper nem fazer barulho quando adultos estivessem conversando.

Os gestos simples, valorizados por Heider (1970), de desprendimento mostram quanto a figura do outro está incorporada a nossa percepção, quanto o outro já faz parte dos momentos em que tenho chance de expressar meu carinho para com ele. Dona Jacira, por exemplo, não se esquece do gesto do neto menorzinho, que guardou a bolachinha recebida na merenda para lhe dar de presente:"É pra você, vó!". Algo parecido acontece quando os netos de dona Rosalina explicam para a professora que, no caso deles, ela tem de dar duas estatuetas de gesso - peças em que as crianças vão aplicar um feltro e um enfeite para oferecer de presente à época do Dia das Mães. “É que nós temos duas mães: a minha mãe e a minha avó", dizem, enternecendo os mais velhos. Ou, então, com dona Betânia, quando a neta vem se dirigir à avó para saber se pode usar determinada blusa branca para ir à escola. "Olhe aí, Paulo, a mãe dela está aí (na cozinha), e é comigo que essa menina vem falar!", apressa-se em registrar aquela senhora.

Nem tudo, porém, resulta em alegria. Os avós que conheci sempre tiveram por norma conversar bastante, aconselhar e até mesmo ralhar com as crianças para definir os limites daquilo que é possível e daquilo que não é possível fazer. O convívio respeitoso com os outros implica necessariamente limites, restrições quanto a ceder aos primeiros impulsos, e as crianças focalizadas nesta pesquisa tinham perfeitas condições de entender isso. Repreensões mais severas existem, sim, mas - conforme dizem os avós - "só quando a boca não vence" (Oliveira, 2011).

A socialização implica um processo em que nos afirmamos como seres habilitados ao convívio social; preparamo-nos para isso e esperamos dos outros, nossos semelhantes, que também o façam. Por isso, a vida societária não é feita apenas da afirmação de meus impulsos e minhas vontades, mas também dos limites que conscientemente desejamos e consagramos para uma convivência respeitosa. Asch (1977, p. 300) mostrou, com precisão cristalina, que os aspectos restritivos, tanto quanto os impulsos, são criados e desejados por nós. Portanto, a liberdade individualizada e absoluta não tem espaço se o valor que se quer fazer prevalecer for um comportamento ético de respeito mútuo entre as pessoas. Recatar-se, conter-se, atentar não apenas aos direitos mas também aos deveres, recuar para perceber melhor, ceder (sem se sujeitar), bem como outras atitudes de recolhimento fazem parte do aprendizado de levar em conta a figura do outro.

Qual criança não gosta de brincar? Mas essas crianças foram formadas de modo a também ajudar nas tarefas domésticas. São os chamados 
servicinhos, que, ao lado dos estudos e das diversões, compõem seu dia a dia. As crianças devem estudar - dizem os avós -, mas devem também saber fazer as coisas. É uma educação no serviço e nas letras, como disse o senhor Benedito, um dos avôs, sintetizando uma preocupação que é de todos. Desse modo, os mais jovens são socializados num contexto que não separa atividades manuais das atividades intelectuais, mas que demanda uma disciplina, a disciplina de trabalho (Oliveira, 2011).

Fica claro também que, nesse processo socializador, nem tudo é ameno, feliz ou amigável. Há, na vizinhança, pessoas que inspiram temor: ladrões, gente briguenta ou que apela sistematicamente para práticas agressivas e intimidadoras, às vezes vinculadas ao uso de drogas. A violência penetra também em brinquedos e brincadeiras, como nos ralos de pipa, em que a linha fica impregnada com vidro moído e pó de ferro. As brigas ocorrem com muita frequência, e derivações cruéis se apresentam até mesmo em brincadeiras aparentemente pacatas, como mão-na-mula, que vira catraca quando as crianças, ao pularem sobre o corpo de quem está curvado, forçam-lhe o pescoço. Ou que se transforma em esmagar o tomate, quando quem pula projeta e impulsiona seu peso sobre as costas do companheiro.

Não é só a violência física que se faz presente; a simbólica também emerge quando alguém resolve declarar, diante de todos que estão próximos, problemas íntimos de determinada pessoa, causando constrangimentos e dores surdas, mas profundas. Reaparece aqui a mesma crueldade infantil assinalada pela personagem central do filme Cría cuervos, de Carlos Saura (1976). Não entendia ela que a infância pudesse ser considerada a época mais feliz da vida e, assim, disse: "recordo de minha infância como um período interminável, triste, em que o medo preenchia tudo... medo do desconhecido".

Outro aspecto da socialização que repercute na vida desses avós e netos está na cultura. A cultura das pessoas pobres, como diz Alfredo Bosi (1987), se constrói fazendo. Não que sejam insensíveis e refratários às influências da cultura de massa. Sofrem quando seus netos contam que a criança amiga comprou um sapato, um vestido, uma boneca, um objeto fora do alcance naquele momento. Assim, também se veem ameaçados pela chamada "socialização antissocial", expressão cunhada por André Gorz para se referir aos efeitos e encantos que a publicidade pode operar nos indivíduos no sentido de perceberem sempre a primazia de seus interesses individuais de consumo em relação a eventuais comprometimentos que sua existência enquanto ser social possa engendrar (Gorz, 2003, p. 67).

Esta é, sem dúvida, uma ameaça constante. Todavia, no cenário aqui focalizado, há espaço para que prevaleça uma percepção de cultura que não fique necessariamente aderida à mercadoria, a um bem de consumo. Nesses momentos mais expressivos, retomando Alfredo Bosi, a cultura se 
manifesta como fruto de um trabalho, de um processo, de um resultado que se conquista. Para ele,"o ser humano será culto se trabalhar e é a partir do trabalho que se formará a cultura. É o trabalho, e não a aquisição do objeto final que interessa" (A. Bosi, 1987, p. 40).

Dessa perspectiva, o processo de socialização dos avós e netos é enriquecedor, e algumas dessas elaborações foram aqui apontadas sumariamente. Acima de tudo, crianças e velhos constroem juntos práticas e significados para suas vidas. Assumem o inacabamento (Lapassade, 1963). E mesmo os mais velhos - de quem não se esperava mais nada - querem mudar, querem aprender e querem ensinar; querem, enfim, recuperar a condição de sujeitos de suas existências. $O$ sinal de que suas vidas estão inacabadas é dado pela presença dos netos. Estes, por sua vez, percebem-se inacabados diante da riqueza de ensinamentos que recebem das narrativas e práticas do passado e da presença operante de seus avós. Não se trata aqui de histórias-feitas, dessas que a tradição literária consagrou às crianças. Não. São histórias vividas. Crianças e velhos podem, assim, comparar formas de socialização. Pode-se discernir como aquilo que a princípio parecia sofrimento - o abandono dos pequenos ou a necessidade de olhar os netos - inaugura no fazer dessas pessoas um novo entrar na vida. Não é um momento de retração; ao contrário, é um momento de despertar as potencialidades que carregamos dentro de nós. Ao reconhecer o outro como diferente, somos levados a perceber nosso inacabamento. Inspirados por Paulo Freire, podemos afirmar que aqui também os homens não se socializam sozinhos; eles se socializam entre si, em comunhão (Freire, 1975).

Aprendemos e crescemos quando as diferenças são mutuamente respeitadas, de modo a que um não sufoque o outro. Compartilhar a vida implica, como diria Simone Weil, assumir que "as diferenças não diminuam a amizade e nem a amizade diminua as diferenças" (citado por E. Bosi, 1983, p. 14). Direitos e deveres devem estar conciliados.

Saber acolher e combinar igualdade e diversidade - eis o desafio. Esta pode ser a chave para desenvolver uma socialização que não seja vertical tampouco sem limites, mas que seja verdadeiramente promotora das interações sociais solidárias, nas quais existem, sim, conflitos e contradições, mas principalmente se faz presente e vigoroso o empenho em superá-los, sem que isso implique a anulação do outro.

Ecléa Bosi (1987) encaminha a síntese dessa orientação: “Quando duas culturas se defrontam não como predador e presa, mas como diferentes formas de existir, uma é para a outra como uma revelação" (p. 16).E assim se mostraram os avós e netos pobres: superaram sua adversidade, recusaram o quadro sombrio da exclusão, reconheceram-se como iguais e diferentes ao mesmo tempo, doaram-se reciprocamente e construíram juntos uma forma afetiva e solidária de socialização. 
Socialização e cultura solidária, uma longa e difícil jornada

Ao acentuar a presença da solidariedade no processo de socialização, queremos retomar o texto de Clastres (1978), para relembrar a feição que ela tomou entre os índios Guaiaqui. A solidariedade aparece entre eles na curiosa relação que estabelecem entre os caçadores da tribo e os animais abatidos. A cultura Guaiaqui preconiza a proibição aos caçadores de comer o animal por eles caçado. A caça deve ser destinada aos outros, até mesmo aos membros da família, mas nunca ao caçador. Comer o animal caçado traz ao infrator a desgraça da pané, pois, segundo acreditavam, a associação entre caçador e animais mortos rompia a conjunção simbólica que resguardava a preservação e a subsistência do grupo, ou seja, a associação entre caçadores e animais vivos, que pudessem vir a abastecer a tribo.

No processo de socialização, a proibição de comer a carne da sua caça inibia eventuais propensões egoístas, assim como a dispersão entre esses índios. Nesse contexto, minha caça é para os outros, e os outros deverão caçar para mim. Todos os homens se tornam, portanto, doadores e recebedores da caça, que é produto do seu fazer. Eis aqui, então, a raiz da solidariedade: ajudo e sou ajudado, mesmo que as ações ocorram em tempos diferentes.

Clastres (1978) explica que a interdição pela qual o indivíduo é levado a separar-se de sua caça inaugura uma rede societária muito sugestiva:

ele se obriga a confiar nos outros, permitindo assim o laço social de maneira definitiva. A interdependência de caçadores garante a solidez e a permanência desse laço. $\mathrm{E}$ a sociedade ganha em força o que estes indivíduos perdem em autonomia. (pp. 80-81)

Eis aí um traço socializador que teria fascinado personalidades tão diversas quanto Durkheim e Antonio Gonçalves da Silva, o Patativa do Assaré, para quem "a principal riqueza da vida é esta fraternidade de um para com o outro; é esta amizade sem sentido de exploração. É eu defender o seu direito e você defender o meu" (Ângelo, 1999, transcrição de $\mathrm{CD}$ ). A mútua dependência é um traço precioso de socialização lembrado por Richard Sennett, pois se afirma como barreira à corrosão do caráter, que tende a ocorrer cada vez que impulsos e percepções mesquinhos se agigantam em nós, aumentando nossa indiferença em relação ao outro (Sennett, 1999).

Temos aí, portanto, o reencontro entre socialização e uma cultura particularíssima, que acaba por promover a interdependência e a solidariedade entre os pares. 
Difícil não pensar, também, na socialização das crianças sioux, tão emblematicamente estudada na Psicologia por Erik Erikson. Para este pesquisador, as sociedades indígenas não podem ser consideradas "etapas infantis da humanidade nem desvios estagnados",e sim "formas completas de vida humana madura, geralmente de uma homogeneidade e uma integridade simples que às vezes bem que poderíamos invejar" (Erikson, 1976, p. 102). Talvez "inveja" não seja a palavra justa. Mais adequado seria admirar essas crianças sioux, que aprendiam desde cedo que o bem supremo estava em possuir alimentos para combater a fome, ter tempo para meditar e alguma coisa para dar de presente aos outros. Nessa tribo, mostra Erikson (1976):"O homem mais menosprezado é o que é rico mas não distribui nem usa sua riqueza com os que o rodeiam. Ele é que é realmente'pobre'"' (p. 118).

Estudar socialização recorrendo a exemplos que vêm das crianças e velhos nas classes populares, assim como de povos indígenas, de contextos e momentos históricos tão diversos, significa uma tentativa de empreender um reencontro com valores e práticas simples e luminosas que a humanidade foi capaz de construir, mas que, predominantemente, não zelou para conservar ou, então, pouco fez para aperfeiçoar. Deixou-se levar, em grande parte, pelo poder avassalador do dinheiro, cedendo primazia aos valores econômicos e aos interesses particularistas. Nada mais simples que cifras e números, diria Weil (1996, p. 137), mas nada também mais brutal para a condição humana. Por isso, reaprender uma perspectiva de generosidade nos leva a uma luta inglória: a luta contra a barbárie, de que fala Walter Benjamin. Conta este autor que:

um velho em seu leito de morte revela a seus filhos a existência de um tesouro escondido em sua vinha; eles só precisariam cavar. E cavaram, cavaram, mas nem sombra do tesouro. Com a chegada do outono, porém, a vinha produz como nenhuma outra na região. Só então eles perceberam que o pai lhes havia legado uma experiência: a bênção não se esconde no ouro, mas no trabalho. (Benjamin, 1986, p. 195)

As pessoas simples, como as aqui tratadas, com esses exemplos singelos e gestos de atenção ao outro, podem oferecer aos psicólogos sociais um campo de reflexão para o discernimento de horizontes de socialização capazes de reabilitar e reavivar nossas mais altas potencialidades. Elas dizem respeito a traços que estão em nosso íntimo, porém, no mais das vezes, estão muito retraídos, tímidos, esquecidos ou até adormecidos dentro de nós.

Se é possível, ou talvez desejável, associar socialização e solidariedade, quando nos dedicamos a pensar na sociedade em que vivemos e no mundo globalizado que nos cerca, fica muito difícil acreditar na força dessa conjunção. Muitos supõem, de fato, que viver solidariamente so- 
mente é possível em pequenas sociedades, entre pessoas que optaram por uma vida distanciada do mundo. É que a sociedade, tal qual a conhecemos, se encontra inteiramente marcada por traços exacerbados de individualismo, pelo desejo de direitos sem a contrapartida dos deveres sociais, pela indiferença em relação ao outro, pela competição sem limites e pela suspeita e reserva entre as pessoas. Haroche (2005) faz uma reflexão apurada sobre o empobrecimento do espaço interior diante do extremo individualismo contemporâneo, que acaba realçando sentimentos de fragilidade e de humilhação. Observa a pesquisadora que, atualmente, as pessoas não mais se atêm, apenas, ao consumo de objetos; atiram-se igualmente ao consumo de si mesmas. Nasce uma espécie de autodestruição nos relacionamentos, nos quais a figura do outro é, reiteradas vezes, transformada em objeto passível de consumo; formam-se, então, relações enviezadas, nas quais seres humanos se enredam nas próprias teias que eles mesmos criaram, sem ter depois como delas se desvencilhar. Bauman (2004) também se deteve a refletir sobre os impulsos individualistas nas interações sociais do mundo atual, assinalando que se mesclam dois momentos sucessivos: o desejo de consumo e o desejo de destruição. O primeiro impulso é o de buscar incessantemente um relacionamento para depois rechaçá-lo, deixando transparecer que aquilo que foi conquistado, exatamente por tê-lo sido, passa em seguida a não mais interessar. É preciso uma nova aventura, igualmente fugaz. Relações duradoras e compromissadas passam a não interessar. Dessa forma, a ideia de uma pessoa colaborar com outra parece ficar cada vez mais distante, como se as interações sociais devessem se restringir tão somente a uma espécie de cálculo entre custo e benefício: admite-se até ajudar o outro, mas apenas se o recebimento de algo em troca for realmente compensador.

Com todos esses obstáculos, nunca é demais relembrar que, mesmo num universo tão fragmentado e marcadamente individualista como o da sociedade em que vivemos, a vida societária não deixa de ser uma experiência coletiva, uma prática vivida em comum com os outros. Não é certamente pautada pela uniformidade, e, sim, mediada por muitas alternativas, interesses opostos e contrastes nada desprezíveis.

No mundo em que vivemos, parece que transgredir virou norma. É o universo do descartável, da rapidez, da voracidade, da volatilidade, mundo em que, como disse Marx, tudo que é sólido se desmancha no ar (Marx, n.d., p. 26). Se esses traços são os que prevalecem, isso não se faz, contudo, sem conflitos. Asch (1977) já havia lembrado: os impulsos fazem parte dos homens do mesmo modo que as barreiras. E tanto uns quanto outros - acrescentamos nós - engendram uma dialética complexa das relações sociais.

Se cresceu a conformidade entre nós, há autores, como Ernesto Sábato, que nos ajudam a identificar essa espécie de degradação da socie- 
dade contemporânea e defendem a necessidade de resistir, diuturna e incansavelmente, à dilapidação da condição humana. Sublinha a importância da "esperança, da necessidade de resistir, lutar, de não deixar as coisas seguirem seu curso. Devemos sempre guardar no espírito certos princípios, não podemos ceder à tentação do nada, sobretudo em nossa época". Afinal, como lembrou Eric Hobsbawm, o mundo não ficará meIhor por conta própria. Tratam-se aqui de valores que não se medem e não se compram, sob pena de desaparecerem enquanto tais. São intangíveis e, ao mesmo tempo, reais; são, além disso, preciosos suportes de referência. Mantê-los demanda persistência e descarte de facilidades. Resistir pode ser belo, mas envolve compromissos, incertezas e sacrifícios. Quantos se dispõem?

O que parece ganhar impulso na sociedade contemporânea é a "gastronomia dos olhos", como disse Balzac: ver tudo e não se envolver com nada. Ou, quando enxergar, não se comprometer, como mostrou Dejours (1999), ao sustentar que cresceram dentro de nós mecanismos coletivos de defesa que remetem à insensibilidade. Afirma ele que, desde os anos 1980, vivemos a

atenuação das reações de indignação, de cólera e de mobilização coletiva para a ação em prol da solidariedade e da justiça, ao mesmo tempo em que se desenvolveram reações de reserva, de hesitação e de perplexidade, inclusive de franca indiferença, bem como de tolerância coletiva à inação e de resignação à injustiça e ao sofrimento alheio. (p. 23)

Poderemos, diante disso tudo, reconstituir um senso comum, capaz de promover a solidariedade e, com ela, faculdades humanas mais elevadas, hoje tão massacradas no interior de nós mesmos? É muito difícil, senão impossível, afirmar.

O que modestamente podemos indicar são ações solidárias levadas a efeito no Brasil e em vários países que caminham nesse sentido. Muitas vezes, são ações desenvolvidas no anonimato, boa parte delas com inspiração religiosa, mas todas ainda amplamente minoritárias. Uma das vertentes mais significativas vem dos empreendimentos da economia solidária, particularmente de cooperativas e de empreendimentos autogeridos, que recriam formas de solidariedade. A associação de grupos de pessoas em organizações de economia solidária se deve essencialmente ao fato de que oferecem oportunidade de emprego e renda aos que foram descartados pelo mercado. Mas, junto a essa chance, vem também a oportunidade de construírem uma proposta em que todos são donos, não há chefes, mas há a responsabilidade de administrar em conjunto, de

3 Entrevista concedida por Ernesto Sábato sobre seu livro La resistencia e reproduzida em trecho na edição do Caderno 2, Cultura, do jornal 0 Estado de S. Paulo, 30 de julho de 2000, p. D-6. 
autogerir seu empreendimento. As pessoas neste universo são incentivadas a uma outra socialização, lastreada em maneiras altruístas de ajuda, no respeito às diferenças, na complementaridade entre os cooperantes, na doação ao outro, constituindo uma cultura solidária. Hoje, são mais de 22 mil os empreendimentos dessa origem mapeados no Brasil. ${ }^{4}$ Neles existem um projeto e uma prática dos mais ambiciosos: o de se mostrar como contraponto e como alternativa à sociabilidade erigida sob a égide do consumo. Essa forma de resistir e propor alternativas ou, explicando melhor, essa potencialidade de apresentar caminhos outros encerra uma riqueza, que talvez seja para nós o maior legado, pois acena para uma vida não apenas diferente, mas socialmente mais edificante e, portanto, melhor.

"Vida melhor", explica Paul Singer,

não apenas no sentido de que poderão consumir mais com menor dispêndio produtivo, mas também melhor no relacionamento com os familiares, amigos, vizinhos, colegas de trabalho e de estudo; (melhor) na liberdade de cada um escolher o trabalho que lhe dá mais satisfação, no direito à autonomia na unidade produtiva, de não ter que se submeter a ordens alheias, de participar plenamente das decisões que o afetam; (melhor) na segurança de cada um saber que sua comunidade jamais o deixará desamparado ou abandonado. (Singer, 2002, pp. 114-115)

Essa é uma socialização em que as pessoas tomam posse de um lugar, ocupam uma posição no andamento das coisas. E esse gesto não inibe, antes estimula, a que o outro também o faça.

Oswaldo Elias Xidieh defendeu que as práticas de cultura enraizadas na alma popular nunca morrem. Sempre ressurgem, modificadas, como testemunhos de uma vida em comum, que se renova em sua matriz de igualdade primordial. Dizia ele, referindo-se à cultura popular, que:

O senso de justiça no mundo rústico. . . repousa na identidade de origem de todos os seres - são todos filhos de Deus - e nas finalidades práticas de cada uma das coisas e criaturas, que formam e rodeiam o mundo dos viventes. (Xidieh, 1993, p. 87)

A socialização inspirada na solidariedade, assim, não é algo novo. Ela está também presente nos primórdios do socialismo, em diferentes tendências, e inspirou os pioneiros de Rochdale, em meados do século XIX, a fundar os princípios cooperativistas. Hoje, essa socialização é apenas retomada, começa a ser recriada e reelaborada. Seu ponto forte é que

4 Dados fornecidos pela Secretaria Nacional de Economia Solidária, do Ministério do Trabalho e Emprego, Brasília, 2007. 
ela não se resume a uma ideia, mas é já uma prática, que tem exemplos concretos a mostrar e que está lastreada no trabalho e na memória de lutas coletivamente organizados. Read (1986) captou bem essa necessidade ao assinalar que:

Nossa maior tarefa é a construção de bases físicas e psicológicas do auxílio mútuo, e podemos levá-la adiante em minha opinião somente pelo processo educativo, mas um processo educativo que tem pouco a ver com o que hoje chamamos educação. .. União social, disciplina social, moral social - não importa como queiramos chamar este sentido de pertencermos uns aos outros, de vivermos em perfeita fraternidade - esse é, ou deveria ser, o objetivo da educação. (pp. 57, 60)

Para nós, cujo trabalho nos devota a pensar, a ensinar e a pesquisar, a disseminação dessa socialização solidária não deixa de ser um desafio; um desafio e também um enigma (Oliveira, 2006). Mauss (2002), em estudo clássico, já havia proposto que

de um extremo a outro da evolução humana não há mais que duas sabedorias. Que adotemos, então, como premissa de nossa vida aquilo que sempre foi e sempre será um princípio: sair de si, doar, livre e obrigatoriamente; não há risco de nos enganarmos. Um belo provérbio Maori diz: "dá o tanto quanto recebes: tudo será maravilhoso".(p. 95)

Oxalá possamos levar a sério o aprendizado desafiador: empenhar-se para florescer entre nós esse princípio e, com ele, a bela anotação de Rosenberg (2008): "quando temos, podemos dar", mas, "quando recebemos, queremos dar" (p. 97). 


\title{
The process of socialization and solidarity
}

\begin{abstract}
We live in a distinctly individualistic and consumerist society, the repercussions of which interfere in the various forms in which sociability develops. Understanding them requires effort, but even more complex is the challenge to find ways of overcoming the impasses involved in these issues. Would it be possible to identify the deep-rooted relations of social coexistence based on solidarity and with the possibility of them spreading widely within society? The discussion starts with socialization based on the verticality of interactions, passing through interpretations where there is room for reciprocal influences between subjects, and ends with a rapprochement between socialization and solidary culture, seeking an alternate path. While still modest, it is real, as experienced by people who are at the same time so close to us and often so remote from our perception.
\end{abstract}

Keywords: Socialization. Reciprocity. Solidarity. Differences. Solidary culture.

\section{Le processus de socialisation et la solidarité}

Résumé. Nous vivons dans une société notamment individualiste et consommatrice, fait dont les répercussions interviennent aux formes diverses par lesquelles se développe la sociabilité. Pour les comprendre, il faut un certain effort, mais de façon plus complexe, cette compréhension passe par le défi de trouver des formes de surmonter les impasses imbriquées dans ces questions. Serait-il possible d'identifier les relations profondement enracinées de cohabitation sociale ancrées dans la solidarité et avec la possibilité d'expansion généralisée au sein de la société? La discussion part de concepts de socialisation basés sur la verticalité des interactions, tout en passant par des interprétations où il $\mathrm{y}$ a de la place pour des influences réciproques entre les sujets et se donne avec liapproximation entre socialisation et culture solidaire, en cherchant un chemin alternatif. Bien que ce chemin soit modeste, il est aussi concret, car il est vécu par des gens qui sont à la fois si proches de nous et très souvent éloignés de notre perception.

Mots-clés: Socialisation. Réciprocité. Solidarité. Différences. Culture solidaire. 


\section{El proceso de socialización y la solidaridad}

Resumen. Vivimos en una sociedad acentuadamente individualista y consumista, lo cual repercute en las diversas formas a través de las cuales se desarrolla la sociabilidad. Entenderlas demanda esfuerzo, si bien es aún más complejo el desafío para encontrar formas de superar las situaciones sin salida relacionadas con tales cuestiones. ¿Sería posible identificar relaciones enraizadas y profundas de convivencia social, permeadas por la solidaridad y con posibilidad de expandirse de forma generalizada en el seno de la sociedad? La discusión parte de conceptos de socialización basados en la verticalidad de las interacciones, pasando por las interpretaciones en las que hay espacio para influencias recíprocas entre los sujetos y concluye con la aproximación entre socialización y cultura solidaria, buscando un camino alternativo. A pesar de modesto, este camino es concreto, ya que es vivenciado por gente que está al mismo tiempo muy cerca de nosotros y, muchas veces, distante de nuestra percepción.

Palabras clave: Socialización. Reciprocidad. Solidaridad. Diferencias. Cultura solidaria.

\section{Referências}

Ângelo, A. (1999). O poeta do povo: vida e obra de Patativa do Assaré. São Paulo, SP: CPC-UMES. (Livro e CD).

Arendt, H. (1988). Entre o passado e o futuro (M. W. B. Almeida, trad.). São Paulo, SP: Perspectiva.

Asch, S. (1977). Psicologia social (4a ed., D. M. Leite \& M. M. Leite, trads.). São Paulo, SP: Nacional.

Bauman, Z. (2004). Amor líquido (C. A. Medeiros, trad.). Rio de Janeiro, RJ: Jorge Zahar.

Benjamin, W. (1986). Experiência e pobreza. In W. Benjamin, Documentos de cultura, documentos de barbárie (pp. 195-198). São Paulo, SP: Cultrix.

Berger, P., \& Luckmann, T. (1985). A construção social da realidade (6a ed., F. S. Fernandez, trad.). Petrópolis, RJ: Vozes.

Berger, P., \& Luckmann, T. (1993). A construção social da realidade (10a ed., F. S. Fernandes, trad.). Petrópolis, RJ: Vozes.

Bosi, A. (1987). Cultura como tradição. In G. Bornheim, A. Bosi, J. A. M. Pessanha, R. Schwartz, S. Santiago \& P. S. Duarte, Cultura brasileira: tradição/contradição (pp. 
31-58). Rio de Janeiro, RJ: Jorge Zahar.

Bosi, E. (1983). Simone Weil, a razão dos vencidos (2a ed.). São Paulo, SP: Brasiliense.

Bosi, E. (1987). Cultura e desenraizamento. In A. Bosi (Org.), Cultura brasileira (pp. 1641). São Paulo: Ática.

Bourdieu, P. (Coord). (1999). A miséria do mundo (M. S. S. Azevedo, trad.). Petrópolis, RJ: Vozes.

Chombart de Lauwe, M. J. (1991). Um outro mundo: a infância (N. M. Kon, M. Levy \& B. P. Haber, trads.). São Paulo, SP: Perspectiva.

Clastres, P. (1978). A sociedade contra o Estado (2a ed., T. Santiago, trad.). Rio de Janeiro, RJ: Francisco Alves.

Dejours, C. (1999). A banalização da injustiça social (L. A. Monjardim, trad.). Rio de Janeiro, RJ: Fundação FGV.

Donfut, C. A. (1988). Sociologie des génération: I'empreinte du temps. Paris: PUF.

Durkheim, É. (1971). A educação como processo socializador: função homogeneizadora e função diferenciadora. In M. M. Foracchi \& L. Pereira (Orgs.), Educação e sociedade (6a ed., pp. 39-48). São Paulo, SP: Nacional.

Durkheim, É. (1977). A divisão do trabalho social (Vols. 1-2, M. I. Mansinho \& E. Freitas, trads.). Lisboa: Presença.

Erikson, E. (1976). Infância e sociedade (2a ed., G. Amado, trad.). Rio de Janeiro, RJ: Zahar.

Fernandes, F. (1979). Folclore e mudança social na cidade de São Paulo (2a ed.). Petrópolis, RJ: Vozes.

Freire, P. (1975). Pedagogia do oprimido (2a ed.). Rio de Janeiro, RJ: Paz e Terra.

Gorz, A. (2003). L'immateriel. Paris: Galilée.

Haroche,C.(2005).Processos psicológicos e sociais de humilhação:oempobrecimento do espaço interior. In I. A. Marson \& M. Naxarra (Orgs.), Sobre a humilhação: sentimentos, gestos e palavras (pp. 31-48). Uberlândia, MG: Edufu.

Heider, F. (1970). Psicologia das relações interpessoais (D. M. Leite, trad.). São Paulo, SP: Pioneira. 
Lapassade, G. (1963). L'entrée dans la vie. Paris: Minuit.

Lévy Jr., M. (1968). Socialização. In F. H. Cardoso \& O. lanni (Orgs.), Homem e sociedade (4a ed., pp. 60-62). São Paulo, SP: Nacional.

Martins, J. de S. (2008). A sociabilidade do homem simples: cotidiano e história na modernidade anômala (2a ed.). São Paulo, SP: Contexto.

Marx, K. (1969). O 18 Brumário. In K. Marx, O 18 Brumário e Cartas a Kugelman (pp. 15143, L. Konder, trad.). Rio de Janeiro, RJ: Civilização Brasileira.

Marx, K. (n.d.). Manifesto do Partido Comunista. São Paulo, SP: Escriba.

Mauss, M. (2002). Essai sur le don: forme e et raison de l'échange dans les société archaiques. http://classiques.uqac.ca/classiques/mauss_marcel/socio_et_ anthropo/2_essai_sur_le_don/essai_sur_le_don.pdf

Oliveira, P. de S. (2006). Cultura solidária em cooperativas: projetos coletivos de mudança de vida. São Paulo, SP: Edusp.

Oliveira, P. de S. (2011). Vidas compartilhadas: cultura e relações intergeracionais na vida cotidiana (2a ed.) São Paulo, SP: Cortez.

Read, H. (1986). A redenção do robô: meu encontro com a educação através da arte (2a ed., F. Nuno, trad.). São Paulo, SP: Summus.

Rosemberg, R. L. (2008). Comunhão e solidariedade. Psicologia USP, 19(1), 95-97.

Saura, C. (Diretor). (1976). Cría cuervos... Lembranças de uma infância [DVD]. Espanha.

Sennett, R. (1999). A corrosão do caráter (3a ed., M. Santarrita, trad.). Rio de Janeiro, RJ: Record.

Singer, P. (2002). Introdução à economia solidária. São Paulo, SP: Perseu Abramo.

Tornatore, G. (Diretor), \& Rizzoli Jr., A. (Produtor). (1992). Estamos todos bem [Filmevídeo]. Itália.

Weil, S. (1996). A condição operária e outros estudos sobre a opressão (2a ed., T. G. G. Langlada, trad.). Rio de Janeiro, RJ: Paz e Terra.

Xidieh, O. E. (1993). Narrativas populares. São Paulo, SP: Edusp. 
Paulo de Salles Oliveira, professor titular do Departamento de Psicologia Social e do Trabalho do Instituto de Psicologia da USP.Endereço eletrônico: psalles@usp.br

Recebido: 13/03/2013

Aceito: $7 / 7 / 2013$ 